\title{
Supervisor Incivility and Employee Silence: Does Chinese Traditionality Matter? ${ }^{1}$
}

\author{
Chang-e LIU \\ Wei Xie Yahui Chen \\ Jie Huang \\ School of Business \\ Mobile E-business Collaborative Innovation Center of Hunan Province \\ Key Laboratory of Hunan Province for Mobile Business Intelligence \\ Hunan University of Commerce Changsha \\ China
}

\begin{abstract}
Research to date has largely been unclear about the relationship between supervisor incivility and employee silence. In the current research, based on social exchange theory, we examine the extent to which Chinese traditionality moderates the relationship between supervisor incivility and employee silence. Collecting 245 employee's data, we show that supervisor incivility is associated with employee silence. Moreover, we find that Chinese traditionality moderates the main effect negatively, such that the higher employees with Chinese traditionality, the weaker the relationship between supervisor incivility and employee silence; the lower employees with Chinese traditionality, the stronger the relationship between supervisor incivility and employee silence; Implications for theory and practice are discussed.
\end{abstract}

Keywords: Supervisor Incivility; Employee Silence; Chinese Traditionality

\section{Introduction}

Under the background of mass innovation in China, it becomes increasing important for enterprises to make employees to share information actively and give some suggestions for company development(Shi, Gao \& Huang., 2012). However, employees usually keep silence in order to protect themselves. Collecting 254 doctor's data, Soubaw et al (2011) found that the respondents usually keep silence on important questions in workplace. Employee silence refers employee withholding any form of genuine expression which including the individual's behavioral, cognitive and/or affective evaluations (Pinder \& Harlos, 2001). The Chinese people follow with the principle of "silence is golden", it is common for employee to respond workplace events with silence. A little research showed that employee silence played a positive role in protecting privacy and avoiding interpersonal conflicts. However, there were majority of studies showed that employee silence had negative impact on employee motivation, and ultimately resulted in job burnout (Cai \& Geng, 2016). Therefore, it is necessary to discover more antecedents of employee silence and eliminate the negative effect. The current research has focused on some positive antecedents, which reduce employee silence, such as trust (Zheng et al.,2008),perceived supervisor support (Li \& Ling, 2010), perceived organizational support (Wang \& Hsieh, 2013) and well-being (Knoll \& Dick, 2013). Scarce research has examined the effect of negative antecedents on employee silence, which mainly focused on abusive supervision (Milliken et al., 2003).Abusive supervision refers to 'subordinates' perceptions of the extent to which their supervisors engage in the sustained display of hostile verbal and nonverbal behaviors, excluding physical contact'(Tepper, 2007).Research to date has little focused on the relationship between supervisor incivility and employee silence, especially in China (Liu et al., 2017).Supervisor incivility has been defined as supervisor's low intensity deviant behavior with ambiguous intent to harm the subordinate, in violation of workplace norms for mutual respect (Anderson \& Pearson, 1999, p.452). Supervisor incivility is link to target' psychological strain, job satisfaction, job attitudes and well-being (Liu et al., 2018).

\footnotetext{
${ }^{1}$ This study was funded by a research grant from the NSFC (71472062;71672056)
} 
In China, it is pervasive in workplace (Liu et al., 2017). Therefore, it is very important to discuss how the supervisor incivility affects employee silence, and when the effect is strong in the Chinese context. With the New Generation becoming the main force in the labor market, work values are varieties in the workplace. Some people regard supervisor incivility as normal behavior while others think it as identity threat. Compared with their parents, the New Generation have lower obedient. Chinese traditionality may explain this phenomenon. Chinese traditionality is rooted in the traditional Chinese culture, which is characterized by Confucianism, Taoism and Buddhism(He, 2010). It refers to the five cardinal relationships (called wu-lun)in Confucianism which include emperor-subject, father-son, husband-wife, older brother-younger brother, and friend-friend. These reflect the cultural dimension of employees' submission to authority (Farh, Earle \& Lin, 1997). That is, subordinate should absolutely obey the norms of "obedience to authority", while superior needn't follow the rules (Xu \& Zhang, 2011). Social exchange theory is a social psychological and sociological perspective that explains social change and stability as a process of negotiated exchanges between parties. It posits that human relationships are formed by the use of a subjective cost-benefit analysis and the comparison of alternatives (Blau et al., 1964). Self-interest and interdependence are central properties of social exchange. That is, in order to achieve a "win-win" in the organization, supervisors and employees will rely on each other (Lawler \& Thye, 1999). Based on social exchange theory, this study will examine the relationship between supervisor incivility and employee silence, and the extent to which Chinese traditionality moderates this relationship. In short, under the background of "mass entrepreneurship and innovation" in China, we examine the relationship between supervisor incivility and employee silence, and the extent to which Chinese traditionality moderates this relationship. It enriches the literature on destructive leadership in one hand and Confucian culture in other hand. It also provides some suggestions to decrease employee silence for management practice.

\section{Literature Review and Hypotheses}

\subsection{The effect of supervisor incivility on employee silence}

Employee silence is an extension of the organization silence. It is widespread in organizations (Pinder \& Harlos, 2001; Scott, 1993). Organization silence was first proposed by Morrison and Milliken (2000), defined as a collective phenomenon where employees withhold their opinions and concerns about potential organizational problems. Based on the research of Pinder and Harlos(2001), they further defined the employee silence as withholding genuine expression about behavioral, cognitive, and/or affective evaluations of organizational circumstances to people who seem capable of changing the situation. In this study, we prefer to adopt the definition of Dyne and Botero (2003), they regard employee silence as the choice of employees after careful consideration and weighing the pros and cons. Meanwhile, they differentiate three types of silence: acquiescent silence, defensive silence, and pro social silence. Acquiescent silence refers to withholding relevant ideas, information, or opinions because of resignation. Defensive silence refers to withholding relevant ideas, information, or opinions as a form of self-protection for fear. At last, pro social silence is defined as withholding work-related ideas, information, or opinions with the goal of benefiting other people or the organization-based on altruism or cooperative motives (Dyne \& Botero, 2003). Supervisor incivility, such as public criticism, slander, sarcasm, questioning and so on, can lead to employee insecurity and perceptions of identity threat. The targets would doubt whether their own efforts and contributions may be respected, and whether they have value to the development of the organization (Aryee, Chen, \& Sun., 2007), as a result, advancing employee silence. According to social exchange theory, individual behavior obeys the rules of reciprocity. The condition of reciprocity is that the two parties can achieve their goals by exchanging their unique resources (Lawler \& Thye, 1999). When individuals get benefits from their leaders, they will create value as a reciprocity (Masterson et al., 2000). While suffered from supervisor incivility, as a return, employees would respond to incivility with tending to keep important information which is very useful for organization development (Wang \& Jiang, 2015). At same time, fear of being a target again, employees usually fear to express their true thoughts or ideas, which also makes employee keep silence in workplace in order to protect themselves (Pinder \& Harlos, 2001). In other words, they will take defensive silence. Therefore, we predict that:

Hypothesis 1:Supervisor incivility has positive relationship with employee silence.

\subsection{The moderating effect of Chinese Traditionality}

Traditionality was first proposed by Schwartz (1992), which refers to the degree to which an individual upholds traditional values. However, Chinese traditionality usually refers to an individual's endorsement of hierarchy. 
It includes fatalism, extensive familism, filial piety, ancestor worship, male domination, and a general sense of powerlessness (Farh, Earle \& Lin., 1997; Yang, Yu, \& Yeh., 1991). In Chinese context, Chinese traditionality is typical and universal phenomenon in the organization (Pillutla et al., 2007). Much empirical research showed that Chinese traditionality moderated the relationship such as organizational justice and organizational citizenship behavior, perceived organizational support and performance, supervisor-subordinate guanxi and counterproductive work behavior etc(Farh et al., 1990; Peng et al., 2011; Cortina \& Magley, 2001). It infers that Chinese traditionality plays an important role in predicting how subordinates respond to their leaders' action. Therefore, we speculate that Chinese traditionality will moderate the relationship between supervisor incivility and employee silence. Farh et al (2007) argue that the individual with high Chinese traditionality obeys traditional social role, while the individual with low Chinese traditionality follows the inducement-contribution balance. When suffered supervisor incivility, the employees with low traditionality would think their contributions can't been identified by supervisor, this would break inducement-contribution balance, ultimately result in employee negative outcome (Wang et al., 2017). The employees with high traditionality, would prefer to respecting the status of supervisors and following the obligation as the social role of the subordinate (Liu et al., 2008). As a result, they would show less employee silence. In short, compared to the employees with low traditionality, the employees with high traditionality would weak the relationship between supervisor incivility and employee silence. Therefore, we predict that:

Hypothesis 2: Chinese traditionality will moderate the relationship between supervisor incivility and employee silence. Such that the positive relationship will be stronger when the employee with low traditionality compared to the employee with high traditionality.

\section{Research Design}

\subsection{Sample and data-collection procedure}

The sample of this study mainly comes from six private company's employees in Hunan and Guangdong province of China. In 2017, we received a total of 300 responses using electronic questionnaires, attaining 263 valid data, and the validity questionnaire rate was $81.7 \% .117$ respondents $(47.9 \%)$ were women. The age of participants ranges from 20 to 50(M=30.98). With regarded to education, 131 respondents were undergraduates $(53.31 \%), 27$ respondents were masters or doctors (11.04\%). 187 respondents $(76.34 \%)$ were employees, 32 respondents $(12.93 \%)$ were supervisors, and 26 respondents $(10.73 \%)$ were senior managers.

\subsection{Measures}

In order to ensure the reliability of measurement tools, we used the mature scales which other researchers have developed. All scales were scored by Likert 5 points ( $1=$ "strongly disagree"; $5=$ "strongly agree"). All scales in this study are described as following:

(1) Supervisor Incivility. Supervisor incivility was measured by Liu and Dai (2012), modifying the original scale developed by Cortina and Magley (2001), which consisted of twelve items that gauge the frequency with which the respondents experienced workplace incivility in dealing with supervisor during the past time. Sample items include "Put you down or was condescending to you" and "Made demeaning or derogatory remarks about you." and so on. The scale's reliability was 0.945 .

(2) Employee Silence. We used employee silence scale by Tangirala and Ramanujam (2008) to assess employee silence, which contains five-items. Sample items include "I have ideas that can improve job performance in the organization, while I did not propose them." and so on. The scale's reliability was 0.946 .

(3) Chinese Traditionality. A five-item scale developed by Farh et al (2007) was used to measure Chinese traditionality. Sample items were "I think the best way to avoid mistakes is to follow the instructions of senior supervisors" and "We should invite the most qualified seniors to make a decision when colleagues are arguing", and so on. The scale's reliability was 0.969 .

(4) Control Variables. We controlled for respondents' demographic variables, including age, gender, education, tenure and occupation in the organization. As previous research suggested that these variables affect employees' behavior (Thau et al., 2009).To ensure the accuracy of the results, these variables are controlled.

\section{Results}

This study uses SPSS21.0 and AMOS17.0 to analysis the data. The steps are as follows: first, doing the descriptive statistical analysis of the data; second, testing the common method bias variation, and analyzing the data problems; third, it analyzes the direct effect and the moderating effect of the Chinese traditionality. 


\subsection{Descriptive statistics and correlation analysis}

The correlation coefficient, mean and standard deviation of the variables in this study are shown in table 1 . Supervisor incivility and employee silence showed strong positive correlation $(\gamma=0.753, \mathrm{P}<0.001)$, and supervisor incivility and Chinese traditionality have a strong negative correlation $(\gamma=-0.350, \mathrm{P}<0.01)$, Chinese traditionality and employee silence have significant negative correlation $(\gamma=-0.285, \mathrm{P}<0.01)$, The above data results preliminarily support the hypothesis of main effect and moderating effect in this study.

Table 1 Descriptive Statistics and Correlations

\begin{tabular}{|c|c|c|c|c|c|c|c|c|c|}
\hline Variable & $\mathbf{M}$ & SD & $\mathbf{1}$ & 2 & 3 & 4 & 5 & 6 & 7 \\
\hline 1.gender & 1.52 & 0.500 & & & & & & & \\
\hline 2.age & 1.62 & 0.929 & -0.129 & & & & & & \\
\hline 3.position & 3.26 & 1.488 & -0.107 & -0.034 & & & & & \\
\hline 4.education & 2.81 & 0.875 & 0.020 & 0.037 & 0.004 & & & & \\
\hline 5 work seniority & 1.37 & 0.742 & -0.101 & $0.513 * *$ & -0.014 & 0.053 & & & \\
\hline $\begin{array}{l}\text { 6.Supervisor } \\
\text { incivility }\end{array}$ & 2.48 & 0.898 & -0.039 & 0.046 & $-0.116^{*}$ & 0.005 & 0.076 & & \\
\hline 7.employees' silence & 2.56 & 0.848 & -0.097 & 0.058 & -0.082 & 0.041 & 0.107 & $0.753 * * *$ & \\
\hline $\begin{array}{l}\text { 8.Chinese } \\
\text { traditionality }\end{array}$ & 3.20 & 1.138 & $-0.006^{* *}$ & $0.080 * *$ & -0.025 & 0.035 & -0.054 & $-0.350 * *$ & $-0.285^{* *}$ \\
\hline
\end{tabular}

\subsection{Common method bias}

To ensure the results, this study used harman single factor to analyze data. This study made unscaled principal component analysis for all variables (Zhou \& Long, 2004). According to the number of factor precipitation or common factor interpretation to determine the size of the common method of deviation, in this study, seven common factors (eigenvalue>1) were extracted from the test results, and the first factor explained variation is $17.57 \%$, less than $50 \%$ (recommended explained variation). It indicated that bias problem of the common method was not serious.

\subsection{Reliability and validity analysis}

The study uses SPSS21.0 statistical analysis software to analyze the reliability and validity of scales. The results are shown in table 2 . Cronbach alpha coefficients of all scales were above 0.80 , indicating that the reliability of the scale is quite high. The KMO values of each scale were all greater than 0.60 , and the results of Bartlett spherical test were significant, and each scale cumulative variances were greater than $50 \%$, indicating good validity.

Table 2 Reliability and Validity Analysis

\begin{tabular}{cccc}
\hline Variable & Cronbach's Alpha & KMO & Cumulative Interpretation Variance \\
\hline supervisor incivility & 0.943 & 0.882 & $61.8 \%$ \\
Chinese traditionality & 0.891 & 0.864 & $82.3 \%$ \\
employees' silence & 0.946 & 0.810 & $61.5 \%$ \\
\hline
\end{tabular}

In this study, AMOS21.0 software was employed to carry out confirmatory factor analysis for the three latent variables of supervisor incivility (SI), Chinese traditionality (CT) and employee silence (ES). The results show that the three-factor model assumed in this study has reached the acceptance criteria $(\mathrm{X} 2 / \mathrm{df}=1.791<2$, RMSEA $=0.050<0.08$, IFI, TLI, CFI are greater than 0.9). The results show that three variables have good convergent validity and discriminant validity. 
Table 3 Confirmatory Factor Analyses

\begin{tabular}{ccccccc}
\hline Model & Factor & $\mathbf{X}^{\mathbf{2}} / \mathbf{d f}$ & RMSEA & IFI & TLI & CFI \\
\hline 1 & three-factor model1 & 1.791 & 0.050 & 0.973 & 0.970 & 0.973 \\
2 & two-factor model 1 & 3.398 & 0.087 & 0.919 & 0.910 & 0.918 \\
3 & two-factor model 2 & 9.139 & 0.160 & 0.724 & 0.694 & 0.723 \\
4 & one-factor model & 15.330 & 0.213 & 0.511 & 0.460 & 0.509 \\
\hline
\end{tabular}

\subsection{Hypothesis testing}

Main effect test. This study uses the method of hierarchical regression analysis to verify the hypothesis, as shown in Table 4, the gender, age, seniority, education and position as a control variable into the regression model. Then, the stepwise entry method is used to put the supervisor incivility into the regression model. As shown in Table 4, the supervisor incivility was positively correlated with employee silence significantly $(\beta=0.748, P<0.001, \mathrm{M} 2)$. Thus, Hypothesis 1 is supported.

\section{Table 4 Regression analysis of direct effects}

\begin{tabular}{|c|c|c|c|}
\hline \multirow{2}{*}{\multicolumn{2}{|c|}{ Type of the Variable }} & \multicolumn{2}{|c|}{ Employee silence } \\
\hline & & M1 & M2 \\
\hline \multirow{5}{*}{ Control variable } & gender & -0.081 & -0.066 \\
\hline & age & -0.007 & -0.009 \\
\hline & seniority & -0.072 & 0.012 \\
\hline & education & 0.038 & 0.037 \\
\hline & occupation & 0.099 & 0.046 \\
\hline \multirow{4}{*}{ independent } & supervisor incivility & & $0.748 * * *$ \\
\hline & $\mathrm{F}$ & 1.626 & 69.763 \\
\hline & $\mathrm{R}^{2}$ & $0.025 * * *$ & $0.575^{* * *}$ \\
\hline & $\Delta \mathrm{R}^{2}$ & 0.010 & 0.566 \\
\hline
\end{tabular}

The moderating role of Chinese traditionality. As shown in table 5, supervisor incivility has a significant positive correlation to employee silence $(\mathrm{M} 4, \beta=0.748, \mathrm{P}<0.001)$, after entering the interactions term between supervisor incivility and Chinese traditionality in model 6 , and the interaction coefficient is $\operatorname{significant}(\beta=-0.340, P$ $<0.01), \mathrm{R}^{2}=0.583(\mathrm{P}<0.001)$, Which indicate that Chinese traditionality play a negative moderating role between supervisor incivility and employees' silence. Hypothesis 2 is supported.

Table 5 Moderated Regression Results

\begin{tabular}{llllll}
\hline \multirow{2}{*}{ Type of the Variable } & & \multicolumn{2}{l}{ employees' silence } & & \\
& & M3 & M4 & M5 & M6 \\
\hline & gender & -0.081 & -0.066 & -0.067 & -0.063 \\
control & age & -0.007 & -0.009 & -0.011 & -0.013 \\
variable & work seniority & -0.072 & 0.012 & 0.012 & 0.006 \\
& education & 0.038 & 0.037 & 0.038 & 0.036 \\
independent & position & 0.099 & 0.046 & 0.046 & 0.061 \\
moderator & SI & & $0.748^{* * *}$ & $0.689^{* * *}$ & $0.562^{* * *}$ \\
Interaction item & $\mathrm{CT}$ & & & $0.026^{*}$ & $-0.273^{*}$ \\
& $\mathrm{SI} \times \mathrm{CT}$ & & & $-0.340^{* *}$ \\
& $\mathrm{~F}$ & 1.626 & 69.763 & 59.751 & 53.897 \\
& $\mathrm{R}$ & $0.025^{* * *}$ & $0.575^{* * *}$ & $0.575^{* * *}$ & $0.583^{* * *}$ \\
& $\Delta \mathrm{R}^{2}$ & 0.010 & 0.566 & 0.565 & 0.572 \\
\hline
\end{tabular}

To show and explain the moderating role of Chinese traditionality in the entire model, the study draws on widely used figure of the moderating role. According to the methods and procedures proposed by Aiken et al (1991), we draw figure of moderating role that the relationship of Chinese traditionality between supervisor incivility and employee silence. We can see the extent to which from this figure, low Chinese traditionality (M-1SD) and high Chinese traditionality $(\mathrm{M}+1 \mathrm{SD})$ have influence on employee silence. 
As shown on Figure 1. Therefore, compared with the low traditional, the employees with high Chinese traditionality can weak the relationship between supervisor incivility and employees silence, and the hypothesis 2 is supported.

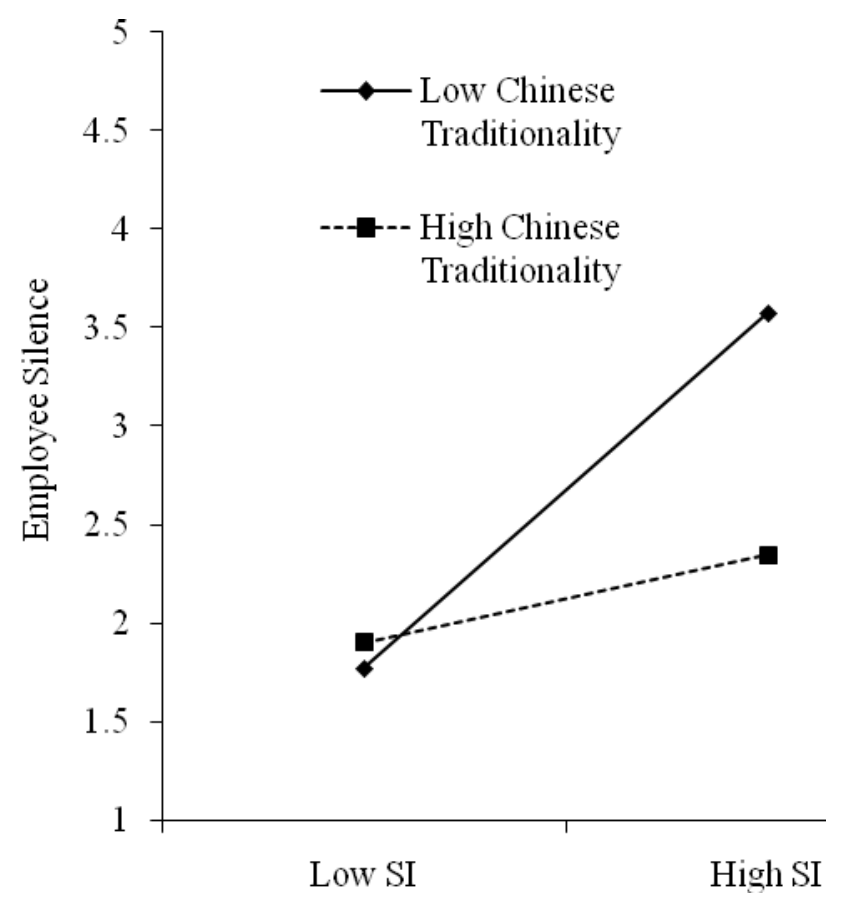

Figure1: Chinese traditionality has a moderator role

\section{Discussion}

This paper mainly focuses on the effect of supervisor incivility on employee silence, especially on the moderator role of Chinese traditionality. It shows that:(1) supervisor incivility significantly has a positive effect on employee silence;(2) Chinese traditionality moderates the main effect negatively, such that the higher employees with Chinese traditionality, the weaker the relationship between supervisor incivility and employee silence; the lower employees with Chinese traditionality, the stronger the relationship between supervisor incivility and employee silence.

\subsection{Theoretical implications}

Our research mainly contributes to literature in two aspects. First, based on the social exchange theory, we explore the relationship between supervisor incivility and employee silence. Most scholars focus on positive antecedents on employee silence, but there is less research to employ supervisor incivility as the antecedent of employee silence. Liu et al $(2017,2018)$ suggested that supervisor incivility, such as public criticism, defamation, ridicule and so on, is very pervasive in Chinese organization which more than $70 \%$ employees experience it. So, employing supervisor incivility as the antecedent is very important. Second, this study suggests that Chinese traditionality moderates the relationship between supervisor incivility and employee silence. Chinese society always emphasize on "hierarchy". That is, in China, supervisor-subordinate power distance usually is emphasized. Farh et al (1997) pointed out that Chinese traditionality is an indigenous Chinese concept. Research to date little focused on the influence of Chinese traditionality. Therefore, we take this variable as a moderate between supervisor incivility and employee silence which has an important influence on the employee's behavior. Meanwhile, it is of great significance to a comprehensive understanding of the individual attitudes and behaviors changes in workplace.

\subsection{Management implications}

The results of this study show that supervisor incivility has an obvious positive effect on employee silence. Therefore, the organization should pay more attention to the leadership behavior (especially the destructive leadership). 
The organization can assess the supervisor regularly and get the assessment data through anonymous survey. It's suggested to conduct reward and punishment mechanism and put the leadership behavior into the performance appraisal system. Meanwhile, the new generation of employees have become the backbone to achieve innovation and development in Chinese enterprises, which is characterized by " the pursuit of freedom and challenges". Therefore, the organization need pay more attention to the adaptability and match of the values between the new generation employees and organizations. At the same time, we also point out that Chinese traditionality moderates the relationship between supervisor incivility and employee silence. Therefore, it is necessary to distinguish with different traditionality characteristics in the organization. Compared to the employee with low Chinese traditionality, employee with high Chinese traditionality would prefer to understanding, following and respecting the supervisor and organization. So, the employee with high Chinese traditionality will have less emotional problems. For organization, on the basis of "taking its essence and going to the dregs" of traditional Chinese culture, it will form the right guidance for employees' attitudes and behavior through training. After strengthening the guidance of correct values and cultural, enterprise will create a positive, optimistic, and peaceful atmosphere of interpersonal communication by the way of clarifying organizational goals and organizing team activities, which ultimately will cultivate employee's sense of responsibility and strengthen employee's sense of participation. The organization should encourage employee's desire to express opinions, and make employees really worry about the enterprise, and gradually tend to break the silence.

\subsection{Limitations and directions for future research}

As with all research, our study has some limitations. First, we only collect the cross-sectional data and ignore the impact of time effects on variables, which makes it difficult to test the dynamic impact of supervisor incivility on employee silence. But our hypothesis model agrees with the research conclusion, namely the leadership behavior can be used as a predictor of employee silence. The conclusion is consistent with the findings of negative side of leadership in organizations. The future researchers can use time series design, and through empirical sampling or field test method to collect horizontal and vertical data, which will make it more accurately to grasp the relationship among variables; Second, it uses the single-source data measurement methods and the conclusions will be influenced easily by the deviation of common method. In this study, employee self-evaluation is used to obtain employee turnover intention data. However, employees are likely to consider their own face problems and have reservations in filling in questionnaire. Therefore, the other evaluation ways are more likely to restore the essence of employee silence. In order to reduce measurement deviation, the suggestions of Podsakoff can be taken. Through protecting the privacy of interviewees, the concern to employees' evaluation will be lower. At the same time, confirmatory factor analysis was conducted on the data, and the results showed that there was a good distinction between the main variables. Therefore, future research can use multi-source or other assessment methods to obtain data to avoid the impact of homologous error.

\section{References}

Anderson, L.M., \& Person, C.M. (1999). Tit for tat? the spiraling effect of incivility in the workplace. Academy of Management Review, 24 (3):113-126.

Aiken, L. S., \& West, S. G. (1991). Multiple regression: testing and interpreting interaction, New bury Park: Sage.

Aryee, S. Chen, Z. X. \& Sun, L. Y. et al. (2007). Antecedents and Outcomes of Abusive Supervision: test of a Trickle-down Model. Journal of Applied Psychology, 92(1): 8-19.

Blau P. M. 1964. Exchange and Power in Social Life, New York: Wiley.

Cai, X, \& Geng, X. L. (2016). The influence of implicit constructive belief on employee silence based on selfprotection motivation- A study of Chinese situation. Science and management of science and technology, 37(10):153-163.

Cortina, L. M., Kabat-Farr, D., \& Magley, V. J. (2017). Researching rudeness: The past, present, and future of the science of incivility. Journal of Occupational Health Psychology, 22(3):299-313.

Cortina, L. M., \& Magley, V. J. (2001). Incivility in the workplace: Incidence and impact. Journal of Occupational Health Psychology, 6(1):64-80.

Dyne, L. V., Ang, S., \& Botero, I. C. (2003). Conceptualizing employee silence and employee voice as multidimensional constructs. Journal of Management Studies, 40(6):1359-1392.

Farh, J. L., Earley, P. C., \& Lin, S. C. (1997). Impetus for action: A cultural analysis of justice and organizational citizenship behavior. Administrative Science Quarterly, 42, 421-444. 
Farh, J. L., Hackett, R. D., \& Liang, J. (2007). Individual-level cultural values as moderators of perceived organizational support-employee outcome relationships in China: Comparing the effects of power distance and traditionality. Academy of Management Journal, 50, 715-729.

He, X. (2010). Why employee known but do not say: an indigenous empirical analysis base of employee silence. NanKai Business Review, (3): 45-52.

Kluemper, D. H., Mossholder, K. W., \& Dan, I. (2018). When Core Self-Evaluations Influence Employees' Deviant Reactions to Abusive Supervision: The Moderating Role of Cognitive Ability. Journal of Business Ethics, (4):1-19.

Knoll, M., \& Dick, R. V. (2013). Do I Hear the Whistle? A First Attempt to Measure Four Forms of Employee Silence and Their Correlates. Journal of Business Ethics, 113(2):349-362.

Lawler, E. J., \& Thye, S. R. (1999). Bringing Emotions into Social Exchange Theory. Annual Review of Sociology, 25(1):217-244.

Li, R., \& Ling, W. Q. (2010). The influence of supervisor support on employees' work attitude and Silence Behavior. Business economy and management, (5):31-39.

Liu, C. E., \& Dai, W. W. (2012). A literature review on workplace incivility. Chinese Journal of Management, 9(7):1092-1097.

Liu, C. E., \& Liu, F. (2011). An empirical study on the relationship between workplace incivility, job satisfaction and turnover intention. Journal of Hunan University of Commerce, 18(2):76-79.

Liu, C. E., Chen, Y.H., Yu, S.X., (2017). Supervisor Incivility, Psychology Safety and Employee Turnover Intention: Does Supervisor-Subordinate Guanxi Matter? International Journal of Business and Social Science, 8(9):79-90.

Liu, C. E., Huang, J. Xie, W. (2018). The Effect of Supervisor Incivility on Employee Creativity: A ChinMediation Model. Jiangsu Social Sciences, 39(3):165-174.

Liu, C. E., Hu, S. M., Yu, S. X., Chen, Y.H., \& Huang, J. (2017). Supervisor Incivility is Related to Employee Creativity: A Locus of Control Explanation of the Mediated Relations. Chinese Journal of Management, 14(9):1315-1323.

Liu, C. E., Hu, S.M., Huang, J, Xie, W. (2017). How does Supervisor Incivility Impair Employees' Knowledge Sharing: Evidence from Chinese Firms? International Journal of Business and Social Science, 8(10):201213.

Liu, D., Liao H., \& Loi, R. (2012). The Dark Side of Leadership: A Three-level Investigation of the Cascading Effect of Abusive Supervision on Employee Creativity. Academy of Management Journal, 55(5):11871212.

Liu, J., Fu, P. P.,\& Zhang, H. N. (2008). The influence of the adoration concept of subordinate authority on the process of confidence Leadership: evidence from the insurance industry. Management review, 20(1):2631.

Masterson, S. S., Lewis, K., \& Goldman, B. M. (2000). Integrating Justice and Social Exchange: The Differing Effects of Fair Procedures and Treatment on Work Relationships. Academy of Management Journal, 43(4):738-748.

Milliken, F. J., Morrison, E. W., \& Hewlin, P. F., (2003). An Exploratory Study of Employee Silence: Issues that Employees Don't Communicate Upward and Why. Journal of Management Studies, 40(6) :1453-1476.

Morrison, E. W., \& Milliken, F. J.,(2000). Organizational Silence: A Barrier to Change and Development in a Pluralistic World. The Academy of Management Review, 25(4):706-725.

Morrison, E. W., \& Milliken, F. J. (2003). Speaking up, remaining silent: The dynamics of voice and silence in organizations. Journal of Management Studies, 40(6):1353-1358.

Peng, Z. L., Liang, D., \& Zhao, H. D. (2011). Supervisor-Subordinate guanxi and the anti-production behavior of the knowledge employee-mediating role of Chinese traditionality. Information magazine, (4):196-200.

Pillutla, M. M., Farh, J. L., \& Lee, C., et al. (2007). An Investigation of Traditionality as a Moderator of Reward Allocation. Group \& Organization Management: An International Journal, 32(2):233-253.

Pinder, C. C., \& Harlos, K. P. (2001). Employee silence: Quiescence and acquiescence as responses to perceived injustice. Research in Personnel and Human Resources Management, (20):331-370.

Schwartz, S. H. (1992).Universals in the content and structure of values: theoretical advances and empirical tests in 20 countries. Advances in Experimental Social Psychology, 25(1):1-65. 
Shi, k., Gao, L. P., Huang, X., \& Sha, J. Y. (2012). The impact of leadership behavior on employee silence: an analysis of the mediating role of trust. Management Review, 24(10):94-101.

Scott, R. L. (1993). 'Dialectical tensions of speaking and silence'. The Quarterly Journal of Speech, 79:1-18.

Tangirala, S. \& Ramanujam, R. (2008). Employee Silence on Critical Work Issues: The Cross-level Effects of Procedural Justice Climate. Personnel Psychology, 61:37-68.

Tepper, B. J. (2007). Abusive Supervision in Work Organizations: Review, Synthesis, and Research Agenda. Journal of Management, 33(3):261-289.

Thau, S., Bennett, R. J., Mitchell, M.S, \& Marrs, M. B. (2009). How management style moderates the relationship between abusive supervision and workplace deviance: an uncertainty management theory perspective. Organizational Behavior and Human Decision Processes, 108(1): 79-92.

Wang, Y. D., \& Hsieh, H. H. (2013). Organizational ethical climate, perceived organizational support, and employee silence: A cross-level investigation. Human Relations, 66(6):783-802.

Wang, R., \& Jiang, J. (2015). How Abusive Supervisors Influence Employees' Voice and Silence: The Effects of Interactional Justice and Organizational Attribution. Journal of Social Psychology, 155(3):204-220.

Wang, Y. Y., Zhang, X. H., \& Han, Y. (2017). Abusive supervision, employee trust and turnover intention: the traditional regulatory role. Leadership Science, (2):45-49.

Yang, G. S., Yu, A. B., \& Ye, M. H. (1991). Chinese personal tradition and Modernity: concept and measurement. Beijing: China Renmin University Press, 241-306.

Zheng, X. T., Ke, J. L., \& Shi, J. T. et. al. (2008). The measurement of employee silence in China and the impact of trust on it. Acta Psychological Sinica,40 (2):219-227.

Zhou, H., \& Long, L. R. (2004). Statistical remedies for common method biases. Advances in Psychological Science, 12(6): 942-950.

Corresponding Author: Yahui CHEN, PHD student at Yunnan University, PHD. E-mail: yahuichen103@163.com 